\title{
BST2 wt Allele
}

National Cancer Institute

\section{Source}

National Cancer Institute. BST2 wt Allele. NCI Thesaurus. Code C154135.

Human BST 2 wild-type allele is located in the vicinity of $19 p 13.11$ and is approximately 3 $\mathrm{kb}$ in length. This allele, which encodes bone marrow stromal antigen 2 , plays a role in the negative regulation of viral infectivity. 